\title{
Resistin increases cisplatin-induced cytotoxicity in lung adenocarcinoma A549 cells via a mitochondria-mediated pathway
}

Wei-Jing Gong ( $\nabla$ weijinggong@hust.edu.cn )

Wuhan Union Hospital https://orcid.org/0000-0003-2114-7514

Tao Zhou

Wuhan Xiehe Hospital: Wuhan Union Hospital

Jia-Qiang Xu

Wuhan Xiehe Hospital: Wuhan Union Hospital

Yi-Fei Huang

Wuhan Xiehe Hospital: Wuhan Union Hospital

Li-Ping Xiang

Wuhan Xiehe Hospital: Wuhan Union Hospital

Fang Zeng

Wuhan Xiehe Hospital: Wuhan Union Hospital

Yong Han

Wuhan Xiehe Hospital: Wuhan Union Hospital

Yong-Ning Lv

Wuhan Xiehe Hospital: Wuhan Union Hospital

Yu Zhang

Wuhan Xiehe Hospital: Wuhan Union Hospital

San-Lan Wu

Wuhan Xiehe Hospital: Wuhan Union Hospital

\section{Research Article}

Keywords: cisplatin, lung cancer, resistin, mitochondria

Posted Date: March 11th, 2021

DOI: https://doi.org/10.21203/rs.3.rs-265516/v1

License: (1) (1) This work is licensed under a Creative Commons Attribution 4.0 International License.

Read Full License 


\section{Abstract}

Lung cancer is the most commonly diagnosed cancer with a high mortality rate. Cisplatin is one of the most important chemotherapeutic agents for the treatment of lung cancer patients, especially in advanced stages. Recent studies showed that cisplatin may interact with mitochondria which may partly account for its cytotoxicity. In the study, we explored the effect of resistin on cisplatin-induced cytotoxicity in A549 cells and assessed whether mitochondria-dependent apoptosis was involved. Our results found that $25 \mathrm{ng} / \mathrm{ml}$ resistin could significantly increase cisplatin-induced apoptosis and G2/M phase arrest, enhance reactive oxygen species generation, exacerbate the collapse of mitochondrial membrane potential, promote the distribution of cytochrome $\mathrm{C}$ in the cytoplasm from mitochondria, and activate caspase 3 . Therefore, the results suggested that resistin might increase cisplatin-induced cytotoxicity via a mitochondria-mediated pathway in A549 cells. However, the precise mechanism has yet to be explored in the future.

\section{Introduction}

Lung cancer is the most commonly diagnosed cancer with a high mortality rate [1]. Every year about 1.80 million people were died of lung cancer, accounting for a quarter of total cancer-related mortality [2]. The 5 -year overall survival rate of lung cancer remains approximately $18 \%$ [3]. Most lung cancer patients are diagnosed at late stages and metastatic when surgical treatment is no longer a viable option. Platinumbased chemotherapy is the primary line treatment for those patients.

Cisplatin is one of the most potent anticancer drugs for the treatment of a wide variety of solid malignancies including ovarian, bladder, lung, testicular cancers [4]. It is generally accepted that cisplatin cytotoxicity mode of action is considered to be mediated by its ability to interact with DNA to form cisplatin-DNA adducts, resulting in a block in DNA replication and transcription, subsequently inducing apoptosis [5]. However, the normal post-mitotic tissues such as kidney, ear, and sensory nerve could be impaired by cisplatin during chemotherapy [6]. Furthermore, mitochondrial DNA is more susceptible to being damaged by cisplatin [7].

Resistin, mainly secreted by macrophages in the tumor microenvironment, was significantly higher in the serum or plasma of cancer patients including lung cancer compared with healthy controls [8]. It was considered an important inflammatory cytokine. Recent studies found resistin not only enhanced the growth and aggressiveness of cancer cells but also was involved in the therapeutic efficacy of several anti-cancer drugs $[9,10]$. However, the role of resistin in cisplatin-induced cytotoxicity in lung cancer cells is still unknown.

In the study, we aimed to explore the effect of resistin on cisplatin-induced cytotoxicity, and examine whether mitochondria involves in cisplatin-induced cytotoxicity in A549 cells.

\section{Materials And Methods}




\section{Cell lines}

Lung adenocarcinoma A549 cells were purchased from Cell Bank of Type Culture Collection of Chinese Academy of Sciences (Shanghai, China). The cells were cultured in RPMI 1640 media supplemented with $10 \%$ fetal bovine serum and grown in a humidified incubator at $37{ }^{\circ} \mathrm{C}$ in a humidified $5 \% \mathrm{CO}_{2}$ atmosphere.

\section{MTS assays}

A549 cells were seeded at 2000 cells/well in 96-well plates and incubated for $12 \mathrm{~h}$ at $37{ }^{\circ} \mathrm{C}$. And then the medium was replaced with a fresh medium containing various concentrations of cisplatin $(0,0.01,0.1,1$, $10,100 \mu \mathrm{M})$ and different concentration of resistin $(0,12.5,25,37.5,50 \mathrm{ng} / \mathrm{ml})$. After $48 \mathrm{~h}$ of incubation, $20 \mu \mathrm{l}$ of CellTiter 96 Aqueous One Solution Reagent (Promega, Madison, WI) was added to each well and incubated for $1.5 \mathrm{~h}$. After that, the absorbance values were determined at $490 \mathrm{~nm}$ in Eon Microplate Spectrophotometer (BioTek. Instruments. Inc, Winooski, VT). Each experiment was conducted in triplicate.

\section{Flow-cytometric analyses of apoptosis and cell cycle}

Flow cytometry was adopted to analyze the apoptosis rate and cell cycle distribution of cells. A549 cells were seeded in a 6-well plate and treated with cisplatin or cisplatin + resistin. After 48 hours, the cells were collected by trypsin. For apoptosis analysis, cells were stained with FITC-Annexin V and Propidium lodide (Beyotime, Jiangsu, China), and analyzed using FC500 Flow Cytometer (Beckman Coulter, Fullerton, CA) with CXP software (Beckman Coulter, Fullerton, CA). For cell cycle analysis, cells were stained with Propidium lodide (Sigma, St. Louis, Missouri, USA) according to the manufacturer's protocol.

\section{Western Blotting}

A549 cells were seeded in a 6-well plate and treated with vehicle, cisplatin, resistin, or cisplatin + resistin for $48 \mathrm{~h}$. Cells were lysed using mammalian protein extraction reagent RIPA (Beyotime, Jiangsu, China) supplemented with protease inhibitor cocktail (Sigma-Aldrich, St. Louis, Missouri, USA). The concentration of total protein was measured using a BCA protein assay kit (Beyotime, Jiangsu, China).

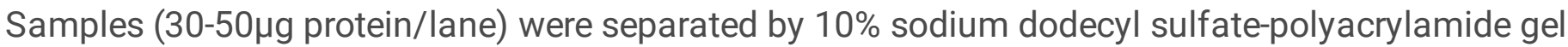
(Beyotime, Jiangsu, China) and then transferred onto the polyvinylidene difluoride membranes (Millipore, Billerica, MA, USA). The membranes were incubated with primary antibodies (primary antibody of cleaved caspase 3 (1:1000, Wanleibio, Shenyang, China), caspase 3 (1:1000, Wanleibio, Shenyang, China), Bcl2 (1:1000, Wanleibio, Shenyang, China), $\beta$-actin (1:10000, Sigma, St. Louis, USA)) at $4{ }^{\circ} \mathrm{C}$ overnight and then incubated with horseradish peroxidase-conjugated secondary antibodies for 1 hour. Protein bands were visualized with ECL substrates (GE Healthcare Bio-Sciences, NJ, USA) using the Western-Light chemiluminescent detection system (Bio-Rad, Hercules, CA, USA) according to the protocols.

\section{Assays of the release of cytochrome $\mathrm{C}$ from mitochondria}


A549 cells were seeded in a 6-well plate and treated with cisplatin or cisplatin + resistin. After 48 hours, the cells were harvested by trypsin. Fractionation of mitochondrial and cytosolic fractions was conducted using the Cell Mitochondria Isolation Kit (Beyotime, Jiangsu, China) according to the protocol. Then, a western blot assay was adopted to assess the protein levels of cytochrome $C$ (primary antibody: 1:1000, Wanleibio, Shenyang, China) in the mitochondria and cytosol as described above. The distribution of cytochrome $C$ was also evaluated by immunofluorescence assay. Briefly, cells were fixed with $4 \%$ paraformaldehyde and incubated with primary antibody against cytochrome C (1:1000, Wanleibio, Shenyang, China) overnight. After washed, cells were immunoblotted with Alexa Fluor-488 conjugated anti-rabbit secondary antibody (Solarbio, Beijing, China) and counterstained with 4'-6-Diamidino-2phenylindole (Beyotime, Jiangsu, China). After that, the cells were pictured with a Leica fluorescence microscope (Leica, Wetzlar, Germany).

\section{Measurement of ROS production}

Flow cytometry and immunofluorescence were used to assess intracellular ROS level with the fluorescent probe of 2',7'-dichlorofluorescein diacetate (DCFH-DA, Beyotime, Jiangsu, China). Cells were incubated with $10 \mu \mathrm{M}$ DCFH-DA for 20 min at $37^{\circ} \mathrm{C}$ and then washed with PBS triple. For flow cytometry analysis, cells were collected by trypsinization and resuspended in $0.5 \mathrm{ml}$ of PBS. The detection wavelength for DCFH-DA was $525 \mathrm{~nm}$. For immunofluorescence, cells were washed and photographed by a Leica fluorescence microscope (Leica, Wetzlar, Germany).

\section{Measurement of mitochondrial membrane potential (MMP)}

Flow cytometry and immunofluorescence were used to assess MMP with the fluorescent probe of 5,5',6,6'-Tetrachloro-1,1',3,3'-tetraethyl-imidacarbocyanine iodide (JC-1, Beyotime, Jiangsu, China). Cells were incubated with $\mathrm{JC}-1$ for $20 \mathrm{~min}$ at $37^{\circ} \mathrm{C}$, then washed with PBS triple. For flow cytometry analysis, cells were collected by trypsinization and resuspended in $0.5 \mathrm{ml}$ of PBS. The detection wavelength for monomeric JC-1 was $525 \mathrm{~nm}$. For immunofluorescence, cells were washed and photographed by a Leica fluorescence microscope (Leica, Wetzlar, Germany).

\section{Measurement of mitochondrial number}

Flow cytometry and immunofluorescence were used to assess the number of mitochondria with the fluorescent probe of Mito-Tracker Green (Beyotime, Jiangsu, China). Cells were incubated with MitoTracker Green for 30 min at $37^{\circ} \mathrm{C}$, then washed with PBS triple. For flow cytometry analysis, the cells were collected by trypsinization and resuspended in $0.5 \mathrm{ml}$ of PBS. The detection wavelength for MitoTracker Green was $525 \mathrm{~nm}$. For immunofluorescence, cells were washed and photographed by a Leica fluorescence microscope (Leica, Wetzlar, Germany).

\section{Statistical analyses}

All data were represented as mean \pm standard deviation (SD) of at least three independent experiments. Pearson's X2 test or Fisher's exact test were applied to analyze differences for qualitative variables. 
Student's t-test or one-way ANOVA was used for continuous variables. All tests were 2-sided, and $\mathrm{P}<0.05$ was considered significant. PASW Statistics v18.0 (IBM Co., Armonk, NY, USA) was used for data analysis.

\section{Results}

\section{Resistin increased cisplatin-induced cytotoxicity in A549 cells}

We evaluated the effect of different concentrations of resistin $(0,12.5,25,37.5,50 \mathrm{ng} / \mathrm{ml})$ on cisplatininduced cytotoxicity in A549 cells at $48 \mathrm{~h}$ by MTS assay. When resistin concentration was $12.5 \mathrm{ng} / \mathrm{ml}$, the IC50 of cisplatin in A549 cells was $8.985 \pm 0.971 \mu \mathrm{M}$, while that of the vehicle group was $9.648 \pm 1.252$ $\mu \mathrm{M}$. However, the IC50 of cisplatin in the $25 \mathrm{ng} / \mathrm{ml}$ resistin group was $2.588 \pm 0.872 \mu \mathrm{M}$ while that of the vehicle group was $10.519 \pm 0.892 \mu \mathrm{M}$. When resistin concentration increased to $37.5 \mathrm{ng} / \mathrm{ml}$, the IC50 of cisplatin became $3.931 \pm 1.032 \mu \mathrm{M}$ (vehicle group: $9.117 \pm 0.901 \mu \mathrm{M}$ ). There were no differences of cisplatin IC50 between the $50 \mathrm{ng} / \mathrm{ml}$ resistin group and the vehicle group (IC50: $8.498 \pm 0.918$ vs $8.962 \pm$ $0.874 \mu \mathrm{M})$. The results showed that $25 \mathrm{ng} / \mathrm{ml}$ resistin could promote cisplatin-induced cytotoxicity in A549 cells (Figure 1a).

To evaluate the effect of resistin on the induction of apoptosis, A549 cells were treated with $2.5 \mu \mathrm{M}$ cisplatin with or without $25 \mathrm{ng} / \mathrm{ml}$ resistin. After stained with Annexin V/Pl, cells were analyzed by flow cytometry. The death rate of $25 \mathrm{ng} / \mathrm{ml}$ resistin $+2.5 \mu \mathrm{M}$ cisplatin group was $62.1 \pm 4.9 \%$, while that of 2.5 $\mu \mathrm{M}$ cisplatin was $39.9 \pm 2.1 \%(P=0.015)$ (Figure $1 \mathrm{~b})$. And the apoptosis rate was similar between the 25 $\mathrm{ng} / \mathrm{ml}$ resistin group and the vehicle group (Supplement Figure 1a). The results showed that resistin could increase cisplatin-induced apoptosis (Figure 1c).

To investigate the effect of resistin on cell cycle distribution, A549 cells were treated with $2.5 \mu \mathrm{M}$ cisplatin with or without $25 \mathrm{ng} / \mathrm{ml}$ resistin for $48 \mathrm{~h}$ and analyzed by flow cytometry. The results showed that resistin could increase the $\mathrm{G} 2 / \mathrm{M}$ phase arrest from $16.1 \% \pm 0.4 \%$ ( $2.5 \mu \mathrm{M}$ cisplatin) to $33.3 \% \pm 2.6 \%$ ( 25 $\mathrm{ng} / \mathrm{ml}$ resistin $+2.5 \mu \mathrm{M}$ cisplatin) Figure $1 \mathrm{~d}$ and $1 \mathrm{e})$.

\section{The effect of resistin on cisplatin-induced ROS production}

Excess generation of intracellular ROS leads to oxidative stress, which is considered one of the key mediators of cisplatin-induced apoptosis signaling [11]. A549 cells were treated with the vehicle group, 25 $\mathrm{ng} / \mathrm{ml}$ resistin group, $2.5 \mu \mathrm{M}$ cisplatin group, and $25 \mathrm{ng} / \mathrm{ml}$ resistin $+2.5 \mu \mathrm{M}$ cisplatin group respectively for $24 \mathrm{~h}$, then stained with DCFH-DA and evaluated under the microscope or by flow cytometry. Compared with the vehicle group, $25 \mathrm{ng} / \mathrm{ml}$ resistin did not significantly affect the production of ROS. However, compared with $2.5 \mu \mathrm{M}$ cisplatin group, the generation of intracellular ROS level was accelerated in 25 $\mathrm{ng} / \mathrm{ml}$ resistin $+2.5 \mu \mathrm{M}$ cisplatin group (the medium fluorescence index increased from $3.05 \pm 0.64$ to $9.15 \pm 0.64$ ) (Figure 2). These results showed that resistin could increase cisplatin-induced ROS production. 


\section{The effect of resistin on the number of mitochondria induced by cisplatin}

Mitochondria is the primary site of aerobic respiration and the principal generator of ROS in cells. It plays a major role in cisplatin-induced apoptosis and oxidative stress [12]. A549 cells were divided into the vehicle group, $25 \mathrm{ng} / \mathrm{ml}$ resistin group, $2.5 \mu \mathrm{M}$ cisplatin group, and $25 \mathrm{ng} / \mathrm{ml}$ resistin $+2.5 \mu \mathrm{M}$ cisplatin group respectively. After $24 \mathrm{~h}$ treatment, Mito-Tracker Green was used to assess the number of mitochondria. Compared with the vehicle group, $25 \mathrm{ng} / \mathrm{ml}$ resistin did not significantly affect mitochondrial number. (Figure 3)

\section{The effect of resistin on mitochondrial membrane potential (MMP) induced by cisplatin}

The maintenance of MMP is significant for mitochondrial integrity and bioenergetic function. The decline of MMP is an early step in cell apoptosis, which is often accompanied by the generation of ROS [13]. After $24 \mathrm{~h}$ treatment, A549 cells were stained with JC- 1 to assess the mitochondrial membrane potential. Compared with the vehicle group, $25 \mathrm{ng} / \mathrm{ml}$ resistin did not significantly affect mitochondrial membrane potential. However, compared with the vehicle group, there was more green fluorescence (JC-1 monomers) instead of red fluorescence (JC-1 aggregates) in the cisplatin group, which indicated cisplatin could reduce mitochondrial membrane potential. While in combined treated cells, the more significant increase of green fluorescence and a decrease of red fluorescence revealed that resistin exacerbated cisplatin-induced collapse of MMP (Figure 4).

\section{The effect of resistin on cytochrome $\mathrm{C}$ distribution induced by cisplatin}

Mitochondrial cytochrome $\mathrm{C}$ is a positively charged soluble protein present in the mitochondria intermembrane space in normal physiology. When the MMP collapse, cytochrome $\mathrm{C}$ could release from mitochondria into cytosol [14]. A549 cells were treated for $24 \mathrm{~h}$, then the distribution of cytochrome $\mathrm{C}$ was also evaluated by immunofluorescence assay. The distribution of cytochrome $\mathrm{C}$ (red color) was more scattered in $25 \mathrm{ng} / \mathrm{ml}$ resistin $+2.5 \mu \mathrm{M}$ cisplatin group than that in $2.5 \mu \mathrm{M}$ cisplatin group. There was no significant difference between the vehicle group and $25 \mathrm{ng} / \mathrm{ml}$ resistin group (Figure 5a). Furthermore, the mitochondrial protein and cytosolic protein were extracted respectively. The expression of cytochrome $\mathrm{C}$ was detected by western blot assay. Compared with the vehicle group, the cytochrome $\mathrm{C}$ expression in mitochondria and cytoplasm was similar in $25 \mathrm{ng} / \mathrm{ml}$ resistin group. However, the expression of cytochrome $C$ in the cytosolic section was higher in $25 \mathrm{ng} / \mathrm{ml}$ resistin $+2.5 \mu \mathrm{M}$ cisplatin group than that in $2.5 \mu \mathrm{M}$ cisplatin group. Similarly, the expression of cytochrome $\mathrm{C}$ in the mitochondrial section was lower in $25 \mathrm{ng} / \mathrm{ml}$ resistin $+2.5 \mu \mathrm{M}$ cisplatin group than that in $2.5 \mu \mathrm{M}$ cisplatin group (Figure $5 \mathrm{~b}$ ).

\section{The effect of resistin on apoptosis relative protein expression}

Caspase 3 is a major mediator of apoptosis that is synthesized as pro-caspase with negligible activity. Its activation depends on proteolytic cleavage of the procaspase into a smaller enzymatically active form. And the enzymatically active caspase (cleaved caspase 3 ) in turn regulates apoptosis and plays an important role in cisplatin-induced cytotoxicity [15]. Next, we investigated if cisplatin-induced cytotoxicity 
in A549 cells was mediated through an intrinsic pathway. After $48 \mathrm{~h}$ treatment, the protein was extracted, and the expression of cleaved caspase 3 , caspase $3, \mathrm{Bcl}-2$ was detected. Compared with $2.5 \mu \mathrm{M}$ cisplatin group, the expression of cleaved caspase 3 was higher in $25 \mathrm{ng} / \mathrm{ml}$ resistin $+2.5 \mu \mathrm{M}$ cisplatin group. And the expression of caspase 3 and Bcl-2 was lower in $25 \mathrm{ng} / \mathrm{ml}$ resistin $+2.5 \mu \mathrm{M}$ cisplatin group than that in $2.5 \mu \mathrm{M}$ cisplatin group (Figure 6). Those results showed that resistin increasing cisplatin-induced cytotoxicity might be mediated by the caspase-3 pathway.

\section{Discussion}

Cisplatin was used extensively for the treatment of numerous solid human tumors including ovarian, bladder, head and neck, lung, and testicular cancers. Traditionally, its action was linked with its crosslink with the purine bases on the DNA, interfering with DNA repair and causing DNA damage[4]. So far, more and more studies showed that mitochondria was an important target of cisplatin for apoptosis, and cisplatin could induce apoptosis via mitochondrial apoptosis pathways [16]. Resistin is a $12.5 \mathrm{kDa}$ cysteine-rich secretory protein, which is mainly secreted by macrophages, dendritic cells, and monocytes [17]. A549 cells were treated with cisplatin and different concentrations of resistin. Our study found resistin could increase cisplatin-induced cytotoxicity in A549 cells, and when resistin was $25 \mathrm{ng} / \mathrm{ml}$, the effect was most remarkable. Resistin could increase the production of ROS and the distribution of cytochrome $\mathrm{C}$ in the cytoplasm, reduce the mitochondrial membrane potential induced by cisplatin.

We found resistin $(12.5 \mathrm{ng} / \mathrm{ml}, 25 \mathrm{ng} / \mathrm{ml}$, and $37.5 \mathrm{ng} / \mathrm{ml})$ could increase cisplatin-induced cytotoxicity. What's more, when resistin concentration was $25 \mathrm{ng} / \mathrm{ml}$, the effect was most remarkable. When resistin concentration increased to $50 \mathrm{ng} / \mathrm{ml}$, resistin did not significantly affect cytotoxicity induced by cisplatin in A549 cells. Our previous studies showed resistin could weakly increase lung adenocarcinoma cell proliferation when resistin concentration was $50 \mathrm{ng} / \mathrm{ml}$ [9]. As a result, resistin might not increase cisplatin-induced cytotoxicity in a dose-dependent manner.

It is widely accepted that the cytotoxicity induced by cisplatin is mediated by the generation of nuclear DNA adducts, which block nuclear DNA replication and/or transcription, resulting in apoptosis [18]. However, cisplatin could exert severe damage on post-mitotic tissues. And a major drawback of cisplatin chemotherapy is severe side effects that cisplatin could impair the function of cells in kidney, ear, and sensory nerve [19]. The accumulation of cisplatin in normal tissues did not entirely determine the toxicity of cisplatin [20], which suggested the nuclear DNA adducts might not be the only mechanism of cisplatin cytotoxicity. Cisplatin could accumulate in mitochondria and form mitochondrial DNA adducts.

Compared with nuclear DNA, mitochondrial DNA was more vulnerable to form DNA adducts [21]. Previous studies showed resistin could affect the production of ROS and mitochondrial function in hepatoma cells [22]. Our previous study found when resistin concentration was $50 \mathrm{ng} / \mathrm{ml}$, resistin could increase ROS production in A549 cells. Compared with the vehicle group, $25 \mathrm{ng} / \mathrm{ml}$ resistin did not significantly affect the production of ROS [9]. However, $25 \mathrm{ng} / \mathrm{ml}$ resistin could increase cisplatin-induced ROS production, reduce the mitochondrial membrane potential, and increase the distribution of cytochrome $\mathrm{C}$ in the cytoplasm. Our results also found the anti-apoptotic protein $\mathrm{Bcl}-2$ was further reduced by resistin, and 
apoptosis protein cleaved caspase- 3 was increased by resistin. So it seemed that resistin increased cisplatin-induced apoptosis through increasing the production of ROS, aggravating the mitochondrial dysfunction, subsequent cytochrome $\mathrm{C}$ release, and activation of caspase 3 . However, the mechanism is still under investigation.

However, Liu's study showed that resistin could induce cisplatin resistance in ovarian cancer cells, which was inconsistent with our results. Liu's study found resistin could significantly increase ovarian cancer cell growth, colony formation, and invasion in $72 \mathrm{~h}$. The IC50 of $25 \mathrm{ng} / \mathrm{ml}$ resistin $+2.5 \mu \mathrm{M}$ cisplatin group was about three times that of $2.5 \mu \mathrm{M}$ cisplatin group. While the growth of ovarian cancer cell was increased over three times by $25 \mathrm{ng} / \mathrm{ml}$ resistin in 72h [23]. So resistin could significantly increase ovarian cancer cells proliferation might partly due to that resistin decreased cisplatin-induced cytotoxicity.

In conclusion, the present study demonstrates that $25 \mathrm{ng} / \mathrm{ml}$ resistin could significantly sensitize cisplatin-induced apoptosis via increasing ROS production, impairing the mitochondria function, activating the caspase 3 pathway. However, the precise mechanism still needs to be further explored. The understanding of the molecular basis of resistin increasing cisplatin-induced cytotoxicity can lead to translational impacts, and provide valuable information for new biomarker selection. It deserves to fully study the role of resistin in cisplatin-induced apoptosis in vivo evaluations in the future.

\section{Declarations}

Author contributions WJG generated, analysis, and interpretated the data and prepared the manuscript. TZ, JQX, YFH, LPX, FZ, YH, and YNL generated, analyzed, and interpretated the data. YZ and SLW generated the idea, and edited the manuscript.

Funding This work was supported by National Natural Science Foundation of China (82003868) and Hubei Provincial Natural Science Foundation of China (2020CFB388).

\section{Compliance and ethical standards}

Conflicts of interest All authors declare that they have no financial or competing interest.

\section{References}

1. Siegel RL, Miller KD, Jemal A. Cancer statistics, 2019. CA: a cancer journal for clinicians. 2019;69(1):7-34.

2. Ferlay J, Colombet M, Soerjomataram I, Mathers C, Parkin D, Piñeros $M$ et al. Estimating the global cancer incidence and mortality in 2018: GLOBOCAN sources and methods. International journal of cancer. 2019;144(8):1941-53.

3. DeSantis CE, Lin CC, Mariotto AB, Siegel RL, Stein KD, Kramer JL et al. Cancer treatment and survivorship statistics, 2014. CA: a cancer journal for clinicians. 2014;64(4):252-71. 
4. Dasari S, Tchounwou PB. Cisplatin in cancer therapy: molecular mechanisms of action. European journal of pharmacology. 2014;740:364-78.

5. Fichtinger-Schepman AM, van der Veer JL, den Hartog JH, Lohman PH, Reedijk J. Adducts of the antitumor drug cis-diamminedichloroplatinum(II) with DNA: formation, identification, and quantitation. Biochemistry. 1985;24(3):707-13.

6. Gong W-j, Peng J-b, Yin J-y, Li X-p, Zheng W, Xiao L et al. Association between well-characterized lung cancer IncRNA polymorphisms and platinum-based chemotherapy toxicity in Chinese patients with lung cancer. Acta Pharmacologica Sinica. 2017;38(4):581-90.

7. Yang Z, Schumaker LM, Egorin MJ, Zuhowski EG, Guo Z, Cullen KJ. Cisplatin preferentially binds mitochondrial DNA and voltage-dependent anion channel protein in the mitochondrial membrane of head and neck squamous cell carcinoma: possible role in apoptosis. Clinical cancer research : an official journal of the American Association for Cancer Research. 2006;12(19):5817-25. doi:10.1158/1078-0432.ccr-06-1037.

8. Gong WJ, Zheng W, Xiao L, Tan LM, Song J, Li XP et al. Circulating resistin levels and obesity-related cancer risk: A meta-analysis. Oncotarget. 2016;7(36):57694-704. doi:10.18632/oncotarget.11034.

9. Gong WJ, Liu JY, Yin JY, Cui JJ, Xiao D, Zhuo W et al. Resistin facilitates metastasis of lung adenocarcinoma through the TLR4/Src/EGFR/PI3K/NF-KB pathway. Cancer science. 2018;109(8):2391-400. doi:10.1111/cas.13704.

10. Sudan SK, Deshmukh SK, Poosarla T, Holliday NP, Dyess DL, Singh AP et al. Resistin: An inflammatory cytokine with multi-faceted roles in cancer. Biochimica et biophysica acta Reviews on cancer. 2020;1874(2):188419. doi:10.1016/j.bbcan.2020.188419.

11. Kleih M, Böpple K, Dong M, Gaißler A, Heine S, Olayioye MA et al. Direct impact of cisplatin on mitochondria induces ROS production that dictates cell fate of ovarian cancer cells. Cell death \& disease. 2019;10(11):851. doi:10.1038/s41419-019-2081-4.

12. Cocetta V, Ragazzi E, Montopoli M. Mitochondrial Involvement in Cisplatin Resistance. International journal of molecular sciences. 2019;20(14). doi:10.3390/ijms20143384.

13. Kalpage HA, Bazylianska V, Recanati MA, Fite A, Liu J, Wan J et al. Tissue-specific regulation of cytochrome $\mathrm{c}$ by post-translational modifications: respiration, the mitochondrial membrane potential, ROS, and apoptosis. FASEB journal : official publication of the Federation of American Societies for Experimental Biology. 2019;33(2):1540-53. doi:10.1096/fj.201801417R.

14. Bock FJ, Tait SWG. Mitochondria as multifaceted regulators of cell death. Nature reviews Molecular cell biology. 2020;21(2):85-100. doi:10.1038/s41580-019-0173-8.

15. Qin S, Yang C, Wang X, Xu C, Li S, Zhang B et al. Overexpression of Smac promotes Cisplatin-induced apoptosis by activating caspase 3 and caspase- 9 in lung cancer A549 cells. Cancer biotherapy \& radiopharmaceuticals. 2013;28(2):177-82. doi:10.1089/cbr.2012.1261.

16. Marullo R, Werner E, Degtyareva N, Moore B, Altavilla G, Ramalingam SS et al. Cisplatin induces a mitochondrial-ROS response that contributes to cytotoxicity depending on mitochondrial redox status and bioenergetic functions. PloS one. 2013;8(11):e81162. 
17. Patel L, Buckels AC, Kinghorn IJ, Murdock PR, Holbrook JD, Plumpton $C$ et al. Resistin is expressed in human macrophages and directly regulated by PPARy activators. Biochemical and biophysical research communications. 2003;300(2):472-6.

18. Jamieson ER, Lippard SJ. Structure, recognition, and processing of cisplatin- DNA adducts. Chemical reviews. 1999;99(9):2467-98.

19. Stadnicki S, Fleischman R, Schaeppi U, Merriam P. Cis-dichlorodiammineplatinum (II)(NSC-119875): hearing loss and other toxic effects in rhesus monkeys. Cancer chemotherapy reports. 1975;59(3):467-80.

20. Stewart DJ, Benjamin RS, Luna M, Feun L, Caprioli R, Seifert W et al. Human tissue distribution of platinum after cis-diamminedichloroplatinum. Cancer chemotherapy and pharmacology. 1982;10(1):51-4.

21. Yang Z, Schumaker LM, Egorin MJ, Zuhowski EG, Guo Z, Cullen KJ. Cisplatin preferentially binds mitochondrial DNA and voltage-dependent anion channel protein in the mitochondrial membrane of head and neck squamous cell carcinoma: possible role in apoptosis. Clinical cancer research. 2006;12(19):5817-25.

22. Zhou L, Yu X, Meng Q, Li H, Niu C, Jiang Y et al. Resistin reduces mitochondria and induces hepatic steatosis in mice by the protein kinase C/protein kinase G/p65/PPAR gamma coactivator 1 alpha pathway. Hepatology. 2013;57(4):1384-93.

23. Qiu L, Zhang GF, Yu L, Wang HY, Jia XJ, Wang TJ. Novel oncogenic and chemoresistance-inducing functions of resistin in ovarian cancer cells require miRNAs-mediated induction of epithelial-tomesenchymal transition. Scientific reports. 2018;8(1):12522. doi:10.1038/s41598-018-30978-6.

\section{Figures}


(a)

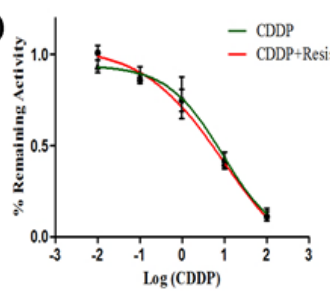

(b)

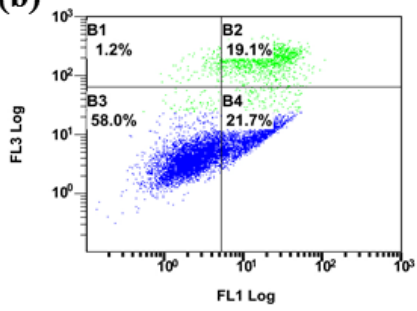

$\operatorname{CDDP}(2.5 \mu \mathrm{M})$
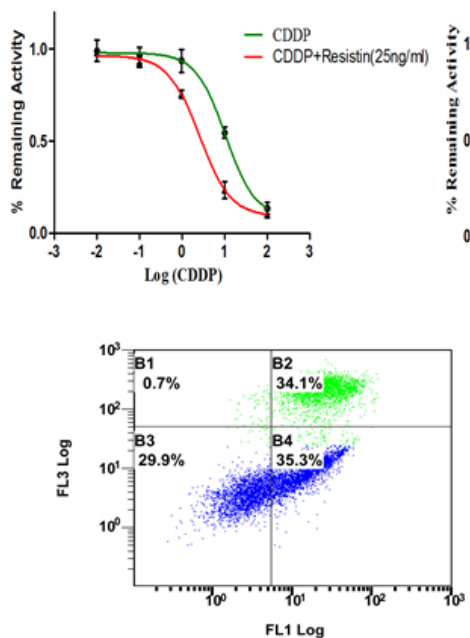

Resistin(25 ng/ml)+CDDP(2.5 $\mu \mathrm{M})$

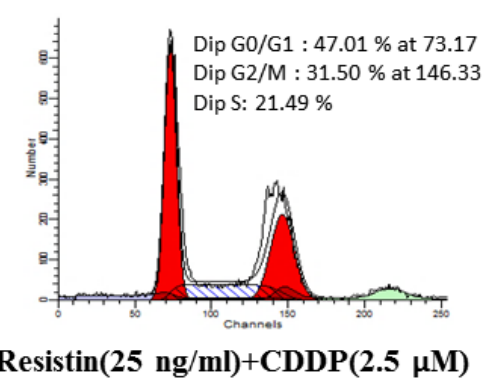

$\operatorname{Resistin}(25 \mathrm{ng} / \mathrm{ml})+\operatorname{CDDP}(2.5 \mu \mathrm{M})$

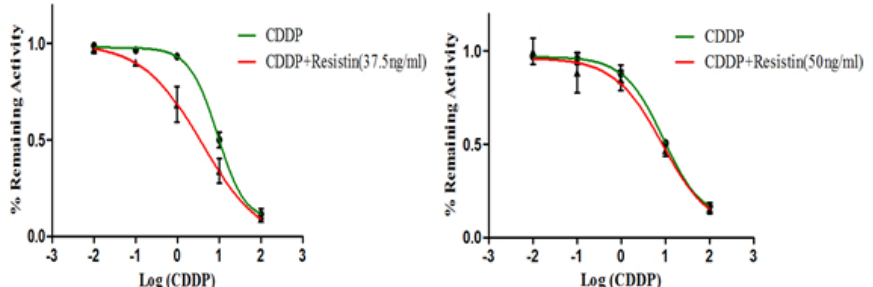

(c)
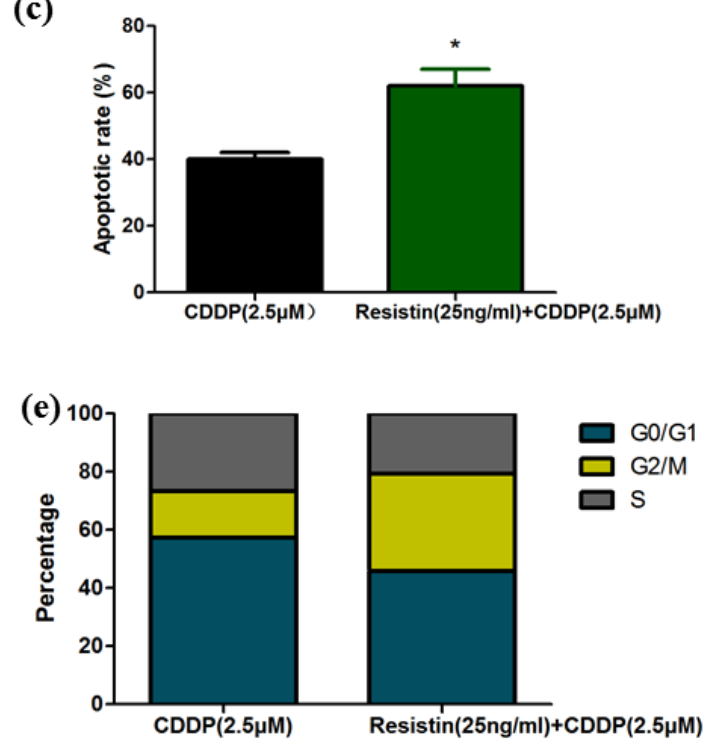

(d)

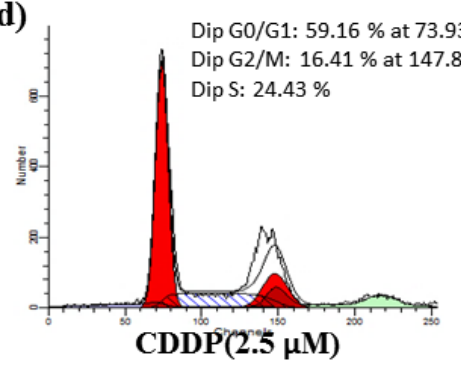

Figure 1

Resistin increased cisplatin-induced cytotoxicity in A549 cells. (a) A549 cells were seeded at 2000 cells/well in 96-well plates, pretreated with or without different concentrations of resistin $(0,12.5,25,37.5$, $50 \mathrm{ng} / \mathrm{ml})$, and then treated with cisplatin $(2.5 \mu \mathrm{M})$ for $48 \mathrm{~h}$. Cell proliferation was detected by the MTS assay; A549 cells were seeded in a 6-well plate, pretreated with or without $25 \mathrm{ng} / \mathrm{ml}$ resistin, and then treated with cisplatin $(2.5 \mu \mathrm{M})$. After 48 hours, cells were lysed, stained with FITC-Annexin V and Propidium lodide, and analyzed by Flow Cytometer for apoptosis (b). Quantitative analysis of the percentage of apoptotic cells (c); A549 cells were seeded in a 6-well plate, pretreated with or without 25 $\mathrm{ng} / \mathrm{ml}$ resistin, and then treated with cisplatin $(2.5 \mu \mathrm{M})$. After 48 hours, cells were lysed, stained with Propidium lodide, and analyzed by Flow Cytometer for cell cycle (d). The results of the cell cycle of different treatments (e). 
(a)

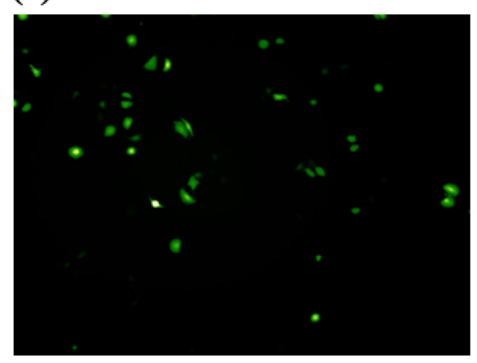

Vehicle

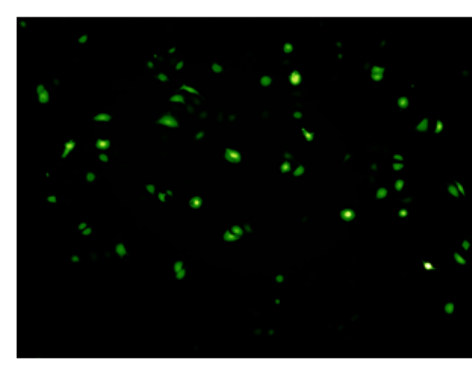

$\operatorname{CDDP}(2.5 \mu \mathrm{M})$

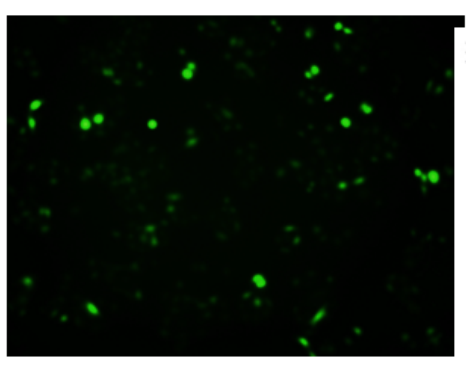

Resistin(25ng/ml)

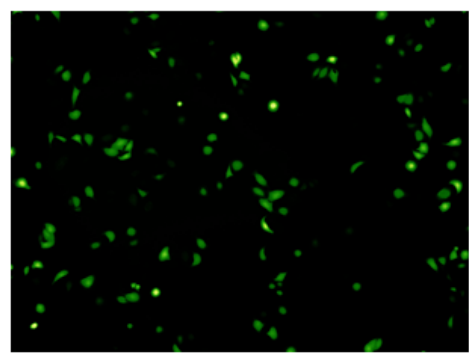

$\operatorname{Resistin}(25 \mathrm{ng} / \mathrm{ml})+\operatorname{CDDP}(2.5 \mu \mathrm{M})$ (b)

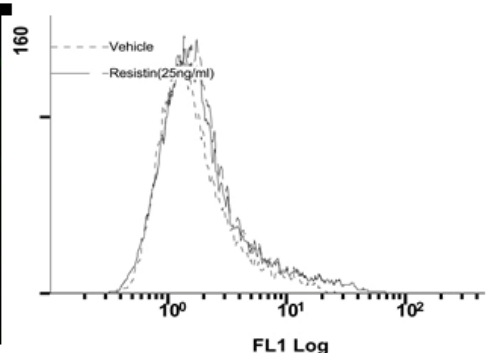

(c)

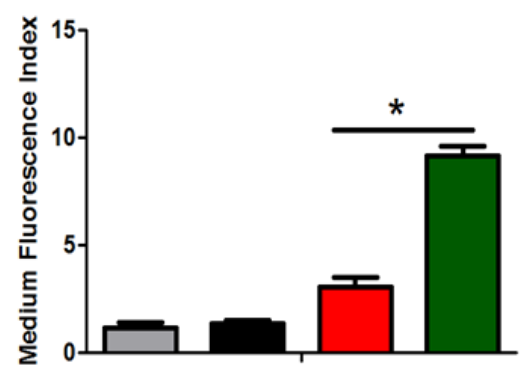

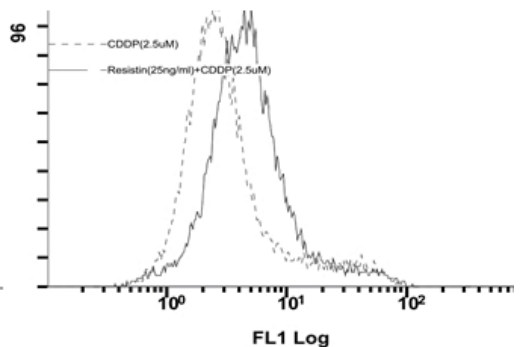

FL1 Log

$\square$ Vehicle

Resistin(25ng/ml)

$\operatorname{CDDP}(2.5 \mu \mathrm{M})$

Resistin $(25 n g / m l)+C D D P(2.5 \mu M)$

\section{Figure 2}

Resistin increased cisplatin-induced ROS production in A549 cells. A549 cells were treated with the vehicle group, $25 \mathrm{ng} / \mathrm{ml}$ resistin group, $2.5 \mu \mathrm{M}$ cisplatin group, and $25 \mathrm{ng} / \mathrm{ml}$ resistin $+2.5 \mu \mathrm{M}$ cisplatin group respectively for $24 \mathrm{~h}$, then stained with DCFH-DA and evaluated under a microscope (a) or by flow cytometry (b). The Quantitative analysis of medium fluorescence index of green fluorescence (c). 
(a)

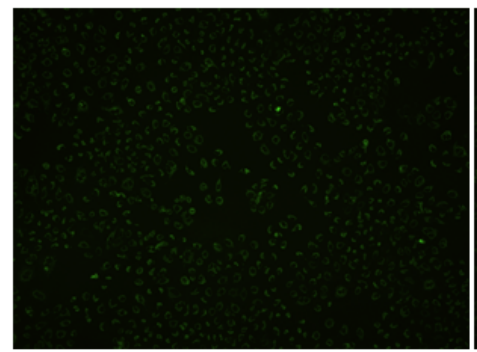

Vehicle

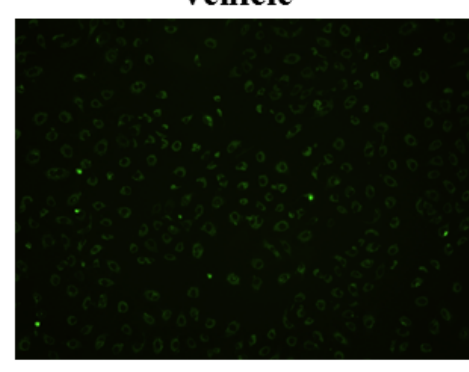

$\operatorname{CDDP}(2.5 \mu \mathrm{M})$ (b)

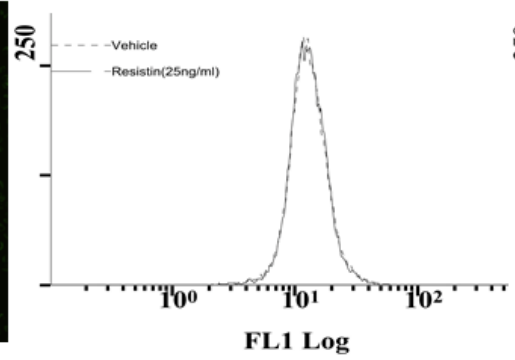

(c)

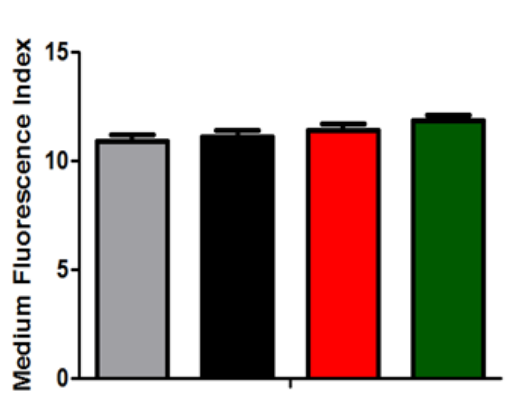

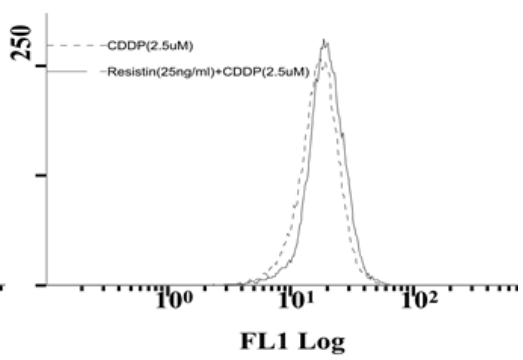

$\square$ Vehicle

Resistin(25ng/ml)

$\operatorname{CDDP}(2.5 \mu \mathrm{M})$

Resistin $(25 n g / m \mathrm{l})+\operatorname{CDDP}(2.5 \mu \mathrm{M})$

\section{Figure 3}

Resistin did not significantly affect the number of mitochondrial induced by cisplatin in A549 cells. A549 cells were treated with the vehicle group, $25 \mathrm{ng} / \mathrm{ml}$ resistin group, $2.5 \mu \mathrm{M}$ cisplatin group, and $25 \mathrm{ng} / \mathrm{ml}$ resistin $+2.5 \mu \mathrm{M}$ cisplatin group respectively. After $24 \mathrm{~h}$ treatment, cells were stained with Mito-Tracker Green and evaluated under a microscope (a) or by flow cytometry (b). The Quantitative analysis of medium fluorescence index of green fluorescence (c). 
(a)

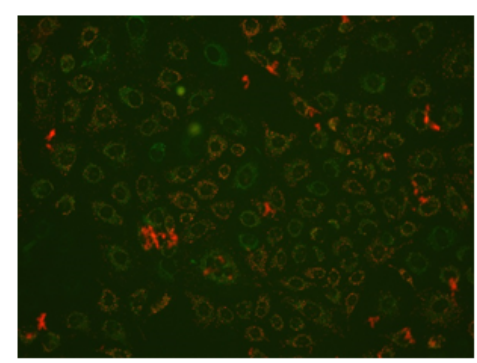

Vehicle

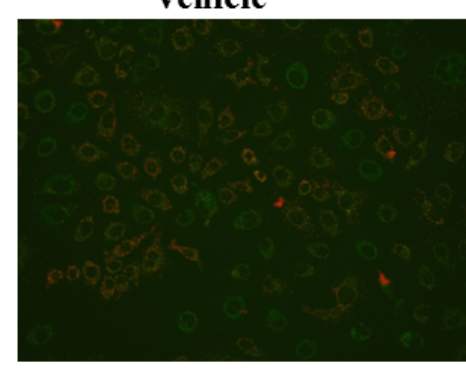

$\operatorname{CDDP}(2.5 \mu \mathrm{M})$ (b)

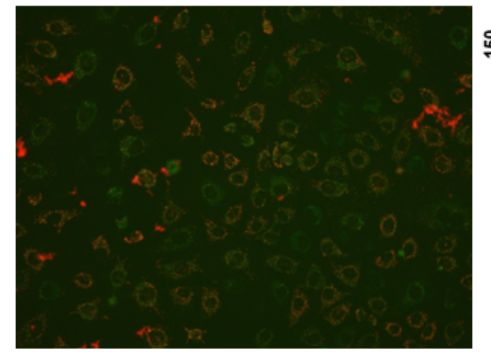

$\operatorname{Resistin}(25 \mathrm{ng} / \mathrm{ml})$

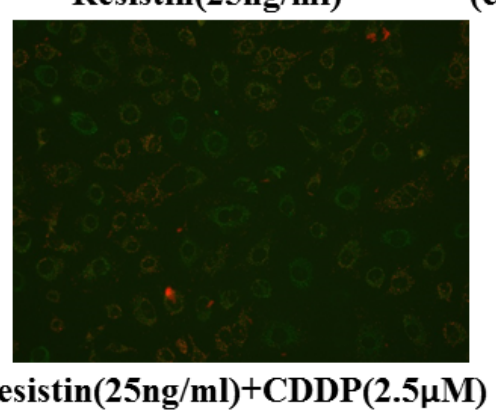

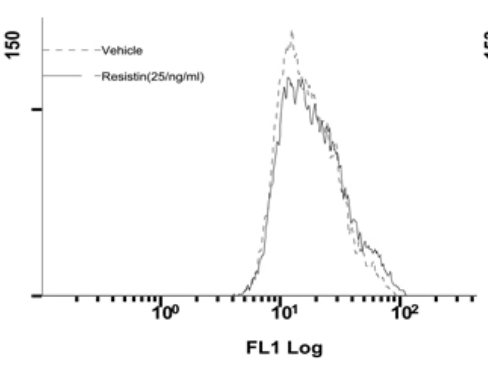

(c)
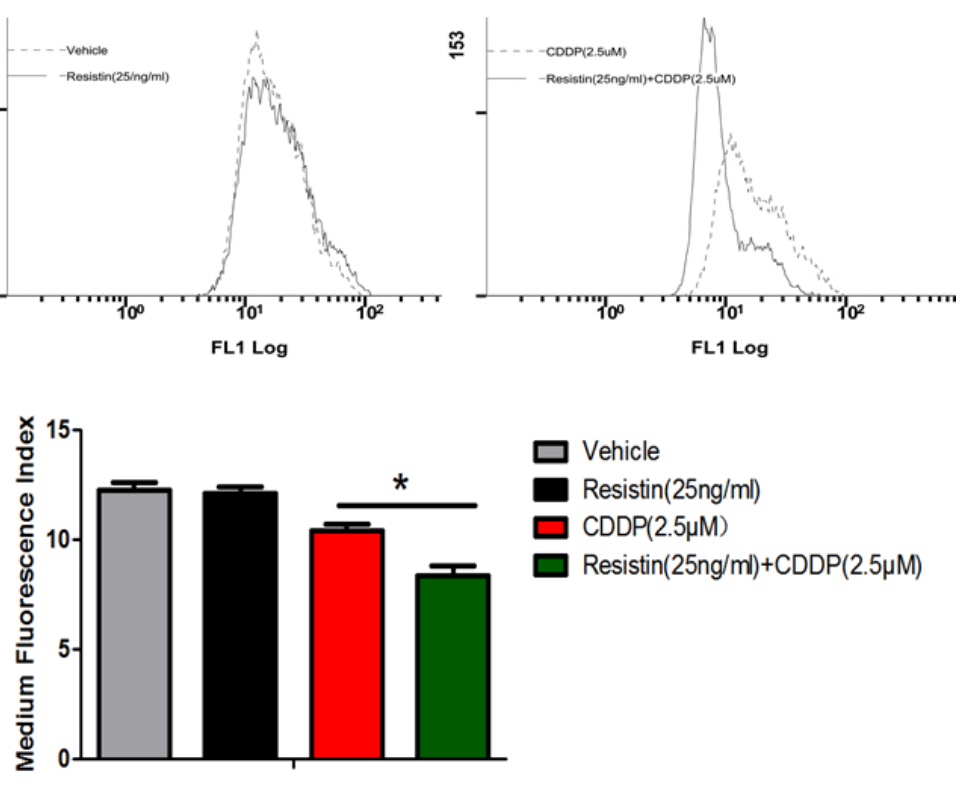

\section{Figure 4}

Resistin decreased mitochondrial membrane potential induced by cisplatin in A549 cells. A549 cells were treated with the vehicle group, $25 \mathrm{ng} / \mathrm{ml}$ resistin group, $2.5 \mu \mathrm{M}$ cisplatin group, and $25 \mathrm{ng} / \mathrm{ml}$ resistin + $2.5 \mu \mathrm{M}$ cisplatin group respectively. After $24 \mathrm{~h}$ treatment, cells were stained with $\mathrm{JC}-1$ and evaluated under a microscope (a) or by flow cytometry (b). The Quantitative analysis of medium fluorescence index of fluorescence (c). 
(a)

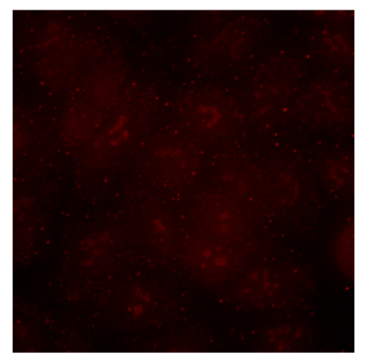

Vehicle

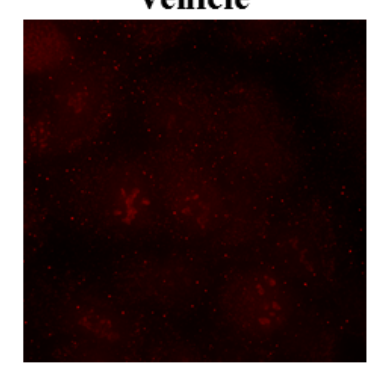

$\operatorname{CDDP}(2.5 \mu \mathrm{M})$

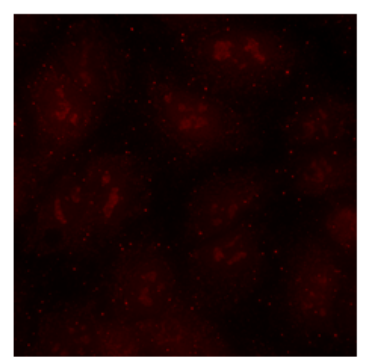

$\operatorname{Resistin}(25 \mathrm{ng} / \mathrm{ml})$

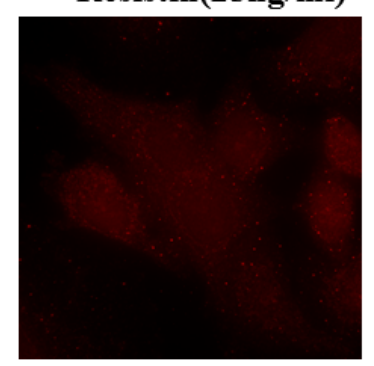

$\operatorname{Resistin}(25 \mathrm{ng} / \mathrm{ml})+\operatorname{CDDP}(2.5 \mu \mathrm{M})$

(b)

\section{Cytosolic}

$\begin{array}{llll}\text { Resistin: - } & + & - & + \\ \text { Cisplatin: - } & - & + & +\end{array}$

Cytochrome C

actin

\section{Mitochondria}

Cytochrome C

actin

\section{Figure 5}

Resistin increased cytosolic cytochrome C levels induced by cisplatin in A549 cells. (a) A549 cells were treated with the vehicle group, $25 \mathrm{ng} / \mathrm{ml}$ resistin group, $2.5 \mu \mathrm{M}$ cisplatin group, and $25 \mathrm{ng} / \mathrm{ml}$ resistin + $2.5 \mu \mathrm{M}$ cisplatin group respectively. After $48 \mathrm{~h}$ treatment, cells were fixed with $4 \%$ paraformaldehyde, and incubated with primary antibody against cytochrome $\mathrm{C}$ overnight. After washed, the cells were immunoblotted with Alexa Fluor-488 conjugated anti-rabbit secondary antibody and counterstained with 4'-6-Diamidino-2-phenylindole. After that, the cells were pictured with a Leica fluorescence microscope; (b) A549 cells were treated with the vehicle group, $25 \mathrm{ng} / \mathrm{ml}$ resistin group, $2.5 \mu \mathrm{M}$ cisplatin group, and 25 $\mathrm{ng} / \mathrm{ml}$ resistin $+2.5 \mu \mathrm{M}$ cisplatin group respectively. After 48 hours, the cells were harvested by trypsin. Fractionation of mitochondrial and cytosolic fractions was conducted using Cell Mitochondria Isolation Kit according to the protocol. Then, a western blot assay was adopted to assess the protein levels of cytochrome $\mathrm{C}$ in the mitochondria and cytosol. 


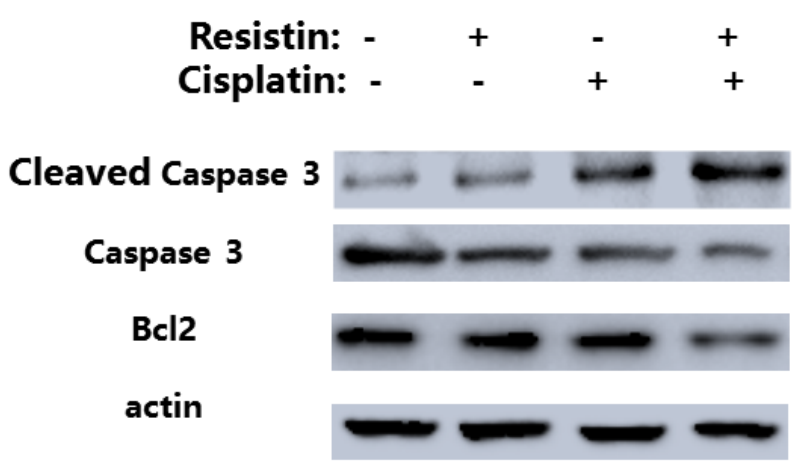

\section{Figure 6}

Resistin increased apoptotic relative protein expression induced by cisplatin in A549 cells. A549 cells were seeded in a 6-well plate and treated with vehicle, cisplatin, resistin, or cisplatin + resistin for $48 \mathrm{~h}$. The cells were harvested by trypsin. Western blot assay was adopted to assess the protein levels of Cleaved Caspase 3, Caspase 3, Bcl-2. 